\title{
Diurnal Enuresis Secondary to Aripiprazole in a Child with Autistic Disorder: A Case Report
}

\section{Öznur Bilaç $\odot$ Akın Tahıllıoğlu $\odot$ Aylin Deniz Uzun $\odot$ Arif Önder $\odot$}

\section{Otizm Tanılı Bir Çocukta Aripiprazole Ikincil Gelişen Diurnal Enürezis: Vaka Bildirimi}

To the Editor;

Aripiprazole is a commonly used second-generation antipsychotic agent for the treatment of schizophrenia, bipolar disorder, and other mood disorders. The Food and Drug Administration (FDA) approved aripiprazole for autism spectrum disorder (ASD)-related irritability such as aggressive symptoms, temper tantrums, and deliberate self-injuriousness in children and adolescents aged 6-17 years. Frequently reported adverse effects of aripiprazole are extrapyramidal symptoms, akathisia and tremor. Diurnal enuresis exists in approximately $10 \%$ of children ${ }^{(1,2)}$. Although drug-induced urinary incontinence is noted as one of the substantial side effects of selective serotonin reuptake inhibitors (SSRIs); reports on antipsychotic-induced enuresis are available ${ }^{(2,3)}$. However, side effects of aripiprazole in children as urinary retention and enuresis has been rarely reported. In particular, there are very little information regarding aripiprazole-induced enuresis in ASD ${ }^{(4-6)}$. In this case presentation, we aimed to report diurnal enuresis developed secondary to aripiprazole treatment in a six-year-old boy with ASD.

\section{CASE}

A 6-year-old boy was referred to our outpatient clinic with complaints of aggressiveness, hyperactivity, repetitive and self-injurious behaviors. According to his developmental history, he was diagnosed with ASD because of verbal developmental delay, lack of eye contact, social-emotional reciprocity and stereotyped behaviors when he was four years old. The case was diagnosed with ASD according to DSM-5 criteria. Risperidone was prescribed at a dose of 0.25 $\mathrm{mg} /$ day; but discontinued because of the drug-related severe sedation. Thus, aripiprazole was started at the dose of $1 \mathrm{mg} /$ day. On the fifth day of aripiprazole treatment, he developed new-onset diurnal enuresis recurring 5-6 times a day for 3 weeks until the medication was stopped.

His medical history, results of physical and neurological examinations and urinalysis were not remarkable. He had urinary bladder control at the age of 3 and had no history of urinary incontinence. Following discontinuation of aripiprazole, his enuresis ceased. After four weeks, due to re-exacerbation of behavioral symptoms, aripiprazole was restarted at a dose of $1 \mathrm{mg} /$ day and then enuresis reappeared and recurred on the fifth day of treatment 5-6 times a day.

\author{
Received: 20.10 .2020 \\ Accepted: 18.01 .2021 \\ First Publication: 20.09.2021 \\ Cite as: Bilaç Ö, Tahıllıoğlu A, Uzun AD, Önder A. Diur- \\ nal enuresis secondary to aripiprazole in a child with \\ autistic disorder: A case report. İzmir Dr. Behçet $\mathrm{Uz}$ \\ Çocuk Hast. Dergisi. 2021;11(3):333-4. \\ Aylin Deniz Uzun \\ Manisa Celal Bayar Üniversitesi \\ Tıp Fakültesi, \\ Manisa, Türkiye \\ aylindeniz268@gmail.com \\ ORCID: 0000-0002-0635-4593 \\ ö. Bilaç 0000-0001-8369-6215 \\ Manisa Celal Bayar \\ Üniversitesi Tıp Fakültesi, \\ Manisa, türkiye \\ A. Tahıllığlu 0000-0002-3952-3672 \\ Ege Universitesi Tıp Fakültesi, \\ Izmir, Türkiye \\ A. Önder 0000-0003-0571-9295 \\ Akdeniz Üniversitesi \\ Tıp Fakültesi, \\ izmir, Türkiye
}

(C) Copyright izmir Dr. Behçet Uz Children's Hospital. This journal published by Logos Medical Publishing. Licenced by Creative Commons 4.0 International (CC BY) 
Drug-induced adverse effects were measured with the Naranjo probability scale ${ }^{(7)}$, which indicated a probable adverse effect associated with aripiprazole. Consequently, we could not maintain the treatment with aripiprazole due to the severity of enuresis. This case study demonstrates the development of diurnal enuresis in a child with ASD when aripiprazole was added to the pharmacological treatment. We also experienced that enuresis disappeared when aripiprazole was discontinued. Moreover, the reoccurrence of enuresis when aripiprazole was used for the second time indicates that the relationship between aripiprazole and enuresis may not be coincidental.

Consistent to our clinical experience, though rarely seen,there are some reports of aripiprazoleinduced urinary retention and enuresis in children $(2,4,5,8)$. Although SSRIs cause enuresis in most of the cases ${ }^{(9,10)}$ and aripiprazole is a treatment option for enuresis ${ }^{(3,11)}$, sometimes aripiprazole might be the reason of nocturnal enuresis ${ }^{(2,5,6)}$. In this case, 5-HT2A antagonism of 5-HT2A receptors on detrusor muscle and the antagonism of alpha-1 receptors on internal sphincter might constitute the mechanisms of enuresis triggered by aripiprazole. In addition, aripiprazole with its serotonin reuptake effect might have another mediating role on enuresis due to cholinergic neuromuscular impact of serotonin on isolated detrusor muscle ${ }^{(10)}$. This is also an important reason of enuresis developing after SSRI use (12). Another enuresis-enhancing effect of aripiprazole may occur through 5 -HT1A system ${ }^{(4)}$. Antagonism of 5-HT1A inhibits bladder contractions ${ }^{(13)}$. Partial agonism of aripiprazole on 5-HT1A receptors may facilitate enuresis by increasing bladder contractions.

Herein, we are reporting a rarely seen case of aripiprazole-induced diurnal enuresis in autistic children. It is noteworthy that most of the case reports of aripiprazole-induced enuresis including the current study have come from Turkey. The etiopathogenesis of this condition is not clear. Frequent use of aripiprazole in ASD in Turkey or an unknown genetic background across Turkish population might be responsible for its more frequent occurrence in our country. Although aripiprazole has become widely common in treating behavioral problems associated with autistic disorder, this case report also highlights that development of enuresis with low doses of aripiprazole should be considered when using it in children with neurodevelopmental disorders such as ASD.

\section{REFERENCES}

1. Bloom DA, Seeley WW, Ritchey ML, \& McGuire EJ. Toilet habits and continence in children: an opportunity sampling in search of normal parameters. The Journal of urology. 1993;149(5):1087-90.

https://doi.org/10.1016/s0022-5347(17)36304-8

2. Bayazıt H, Kılıçaslan F. Diurnal enuresis secondary to aripiprazole. Mustafa Kemal Üniv Tıp Derg. 2017;8(31):36-8. https://doi.org/10.17944/mkutfd.376533

3. Lee MJ, \& Kim CE. Use of aripiprazole in clozapine induced enuresis: report of two cases. Journal of Korean Medical Science. 2010;25(2):333-5. https://doi.org/10.3346/jkms.2010.25.2.333

4. Bozkurt H, Abali O. Aripiprazole-Induced Enuresis in a Child with Autistic Disorder. Archives of Neuropsychiatry. 2011;48:164-6.

5. Karakurt MN, \& Süren S. Desmopressin Use in the Treatment of Aripiprazole-Induced Nocturnal Enuresis in a Child Diagnosed with Autıstıc Disorder. Journal of Child and Adolescent Psychopharmacology. 2015;25(6):518-9. https://doi.org/10.1089/cap.2015.0003

6. Gunes S. Aripiprazole-related diurnal enuresis in children: 2 cases (aripiprazole-related enuresis). Clinical Neuropharmacology. 2017;40(4):175-6. https://doi.org/10.1097/WNF.0000000000000223

7. Naranjo, CA, Busto U, Sellers EM, Sandor P, Ruiz I, Roberts $E A$, et al. A method for estimating the probability of adverse drug reactions. Clinical Pharmacology and Therapeutics. 1981;30(2):239-45. https://doi.org/10.1038/clpt.1981.154

8. Yalcin O. Micturition difficulty and urinary retention associated with aripiprazole and citalopram treatment in a male adolescent with Asperger syndrome. Journal of Child and Adolescent Psychopharmacology. 2014;24(10):598-9. https://doi.org/10.1089/cap.2013.0111

9. Candura SM, Messori E, Franceschetti GP, D’Agostino G, Vicini D, Tagliani M, et al. Neural 5-HT4 receptors in the human isolated detrusor muscle: effects of indole, benzimidazolone and substituted benzamide agonists and antagonists. British journal of pharmacology. 1996;118(8):1965-70. https://doi.org/10.1111/j.1476-5381.1996.tb15631.x

10. Ozdemir PG, Aydın A, Gulec M, Cim EFA. Switching to Fluoxetine in a Case of Sertraline-Induced Urinary Incontinence: A Case Report. Duşunen Adam J Psychiatry Neurol Sci. 2013;26(1):117-8.

11. Kılınç $S$, Hergüner $A$, \& Hergüner $S$. Cessation of Nocturnal Enuresis with Aripiprazole. Journal of child and adolescent psychopharmacology. 2017;27(2):213-4. https://doi.org/10.1089/cap.2016.01276

12. Hergüner S, Kilinçaslan A, Görker I, Tüzün U. Serotoninselective reuptake inhibitorinduced enuresis in three pediatric cases. Journal of child and adolescent psychopharmacology. 2007;17(3):367-9. https://doi.org/10.1089/cap.2006.0070

13. Testa R, Guarneri L, Poggesi E, Angelico P, Velasco C, Ibba M, et al. Effect of several 5-hydroxytryptamine(1A) receptor ligands on the micturition reflex in rats: comparison with WAY 100635. The Journal of pharmacology and experimental therapeutics. 1999;290(3):1258-69. 